\title{
PERMASALAHAN MANAJERIAL DAN KEUANGAN PADA KOPERASI YANG MENGALAMI KENDALA DALAM PENYELENGGARAAN RAPAT ANGGOTA TAHUNAN
}

\author{
Lilik Handajani ${ }^{*}$ ), Budi Santoso dan Ahmad Rifa'i \\ Program Studi Magister Akuntansi Fakultas Ekonomi dan Bisnis \\ Universitas Mataram \\ Jl. Majapahit 62, Mataram 83125, Lombok - Indonesia \\ ${ }^{*}$ Alamat korespondensi : lilikhandajani@unram.ac.id
}

\begin{abstract}
ABSTRAK
Bentuk akuntabilitas dalam pengelolaan koperasi adalah penyelenggaraan Rapat Anggota Tahunan (RAT) yang dilakukan secara periodik. RAT merupakan media bagi pengurus koperasi untuk mempertanggungjawabkan pengelolaan pengurus kepada anggota koperasi serta sarana untuk membahas rencana kerja koperasi ke depan. Melalui penyelenggaraan RAT secara periodik setiap tahun diharapkan koperasi dapat berkembang semakin pesat sehingga mampu memberikan kesejahteraan bagi para anggotanya. Namun demikian, faktanya masih banyak koperasi yang belum bisa menyenggarakan RAT karena terkendala masalah manajerial dan keuangan yang berdampak koperasi tidak berjalan sesuai dengan tujuan awal pembentukan koperasi yaitu untuk meningkatkan kesejahteraan anggotanya. Kegiatan pengabdian kepada masyarakat ini bertujuan mengidentifikasi dan menganalisis masalah-masalah internal yang menyebabkan koperasi tidak mampu menyelenggarakan Rapat Anggota Tahunan, terutama pada koperasi-koperasi dengan status aktif yang tidak menjalankan RAT di Wilayah Lombok Barat. Kajian difokuskan pada aspek manajerial dan keuangan sebagai faktor internal organisasi yang dianggap mampu memberikan solusi dalam pengelolaan koperasi. Kegiatan pengabdian kepada masyarakat ini dilaksanakan melalui kunjungan lapangan dan wawancara mendalam (in-depth interview) terhadap pengurus koperasi yang belum menyelenggarakan RAT sesuai kewajiban pengelolaan koperasi, brainstorming dan pelibatan tenaga PPKL (Petugas Pendamping Koperasi Lapangan) serta telaah terhadap peran regulasi kelembagaan dari Dinas Koperasi yang terkait dalam menjalankan fungsi pengawasan dan pembinaan bagi koperasi. Hasil kegiatan ini dapat merumuskan brief policy tentang masalah manajerial dan keuangan yang menjadi kendala dalam penyelenggaraan RAT dan merumuskan pendekatan dan solusi perbaikan yang diperlukan untuk mengatasi permasalahan dan kendala dalam pengelolaan, pengawasan dan pembinaan koperasi oleh Dinas Koperasi, pengurus dan dewan pengawas koperasi untuk meningkatkan akuntabilitas koperasi. Hasil dari kegiatan pengabdian masyarakat ini dapat memberikan implikasi tentang pentingnya penerapan regulasi, aturan dan sanksi yang tegas tentang kewajiban pelaporan akuntabilitas penyelenggaraan koperasi dalam bentuk RAT, optimalisasi
\end{abstract}


fungsi pendampingan dari tenaga PPKL serta dari dinas terkait dalam melakukan pembinaan dan pengawasan terhadap koperasi-koperasi melalui pendampingan keuangan dan manajerial serta manajemen usaha koperasi.

Kata-kata kunci : Rapat Anggota Tahunan (RAT), koperasi, akuntabilitas

\section{PENDAHULUAN}

\section{Undang-Undang koperasi}

Nomor 25 tahun 1992 menyatakan

bahwa Koperasi merupakan badan

usaha yang beranggotakan orang-

orang atau badan hukum koperasi

dengan melandasaskan kegiatannya

pada prinsip koperasi sekaligus sebagai

gerakan ekonomi rakyat yang

berdasarkan asas kekeluargaan.

Dengan melihat definisi tersebut maka

pembentukan koperasi adalah

bertujuan untuk kesejahteraan

anggota. Manifestasi dari tujuan

koperasi tersebut diharapkan tidak

hanya memberikan kontribusi

terhadap pertumbuhan ekonomi,

melainkan juga menciptakan

pemerataan ekonomi serta

memberdayakan masyarakat

(Nasution, 2008). Dengan demikian

ketika koperasi dikelola dengan baik

oleh para pengurus yang telah diplih

dan ditunjuk oleh anggota koperasi

maka tujuan koperasi untuk meningkatkan kesejahteraan para anggotanya dapat tercapai.

Rapat Anggota Tahunan (RAT)

merupakan

bentuk

pertanggungjawaban

pengurus

terhadap anggota atas pengelolaan

koperasi. Dalam RAT pengurus

menyampaikan pertanggungjawaban

pelaksanaan tugas yang telah

diamanatkan oleh anggota pada tahun buku sebelumnya, serta bersama anggota merencanakan kegiatan untuk tahun buku berikutnya. RAT setidaknya dilaksanakan satu kali dalam tahun buku, khususnya untuk meminta keterangan dan pertanggungjawaban Pengurus dalam melaksanakan tugasnya. Hasil keputusan Rapat Anggota dilaporkan kepada pejabat yang berwenang, paling lambat 1 (satu) bulan setelah tanggal pelaksanaan Rapat Anggota. Dalam RAT selain disampaikan pertanggungjawaban pengurus kepada anggota, juga dilakukan 
perencanaan usaha untuk

pengembangan koperasi di masa

mendatang serta masalah-masalah yang timbul dalam pengelolaan koperasi. Dalam RAT dilakukan pertanggungjawaban berupa pelaporan keuangan koperasi atas kinerja pengurus dalam mengelola koperasi yang terdiri dari Perhitungan Hasil Usaha, Neraca, Laporan Arus Kas dan Laporan Promosi Anggota (Rudianto, 2010).

Sebagai salah satu pilar ekonomi, namun koperasi selama ini masih kalah dengan BUMN dan perusahaan swasta, ini terlihat dari banyaknya koperasi yang telah dibekukan oleh pemerintah karena tidak aktif lagi (Antaranews.com, 2015). Meskipun RAT menjadi keharusan dalam pertanggungjawaban badan usaha koperasi, tetapi faktanya banyak koperasi yang tidak menyelenggarakan RAT maupun menemui kendala untuk melaksanakan RAT. Pada tahun 2015 Kementerian koperasi telah mengeluarkan 62.000 unit koperasi tidak aktif yang tidak lagi menyelenggarakan Rapat Anggota Tahunan dari Data Base koperasi (Ismadi, 2015).

Alasan koperasi tidak menyelenggarakan RAT bisa beragam penyebabnya, mulai dari permasalahan manajerial, perkembangan usaha maupun aspek keuangan. Tentu hal seperti ini akan menghambat perkembangan koperasi untuk tetap survive dan mempertahankan keberadaannya dalam fungsinya untuk meningkatkan kesejahteraan anggota. Lebih jauh lagi ketidakmampuan koperasi dalam menyelenggarakan RAT dalam dua tahun berturut-turut dapat berpotensi menyebabkan koperasi dinonakatifkan dan dibekukan usahanya serta dibubarkan. Hal ini sesuai yang dikemukakan dalam Permenkop dan UKM RI No. 19/Per/M.KUKM/IX/2015. Pasal 20 Ayat 3 menyatakan bahwa untuk melindungi kepentingan koperasi, anggota, dan pihak ketiga, maka terhadap koperasi yang tidak melaksanakan Rapat Anggota Tahunan dikenakan sanksi administratif. Jika Koperasi tidak RAT selama 2 (dua) tahun buku, maka Menteri melalui 
dinas terkait dapat menjatuhkan sanksi administratif berupa, teguran tertulis sekurang kurangnya dua kali, larangan untuk menjalankan fungsi sebagai pengurus atau pengawas koperasi, pencabutan izin usaha dan atau pembubaran oleh Menteri (Andrian, 2015).

Kondisi seperti ini tentu saja diharapkan tidak terjadi karena akan merugikan anggota koperasi sehingga perlu pengelolaan koperasi yang akuntabel. Penegasan tentang pentingnya akuntabilitas koperasi juga telah dinyatakan dalam Peraturan Menteri Negara Koperasi dan UKM RI Nomor 20/Per/M.KUKM/IX/2015 tentang Penerapan Akuntabilitas Koperasi yang menjelaskan bahwa dalam rangka meningkatkan manajemen koperasi yang lebih berdayaguna, berhasilguna, dan bertanggungjawab, koperasi harus meningkatkan kepercayaan kepada anggota dan masyarakat serta pemerintah, untuk itu perlu penerapan akuntabilitas secara tertib dan berkelanjutan berdasarkan prinsip-prinsip koperasi dan tata kelola manajemen yang baik.
Koperasi-koperasi yang berada di wilayah Lombok Barat telah berkembang pesat yang ditunjukkan dengan koperasi aktif yang rutin menjalankan RAT setiap tahun. Namun demikian masih ditemui permasalahan yang berkaitan dengan koperasi-koperasi dengan status aktif tapi tidak menjalankan kewajiban RAT. Hal ini akan menimbulkan permasalahan baik secara internal koperasi terkait pertanggungjawaban maupun dari aspek kinerja kelembagaan dari Dinas Kopearsi sebagai regulator karena rasio koperasi aktif yang melaksanakan RAT akan mengalami penurunan. Oleh karena itu diperlukan upaya untuk mengatasi permasalahan yang dihadapi koperasi yang mengalami kesulitan dam penyelenggaraan RAT sehingga dapat diperoleh pendekatan yang tepat sesuai masalah riil yang dihadapi koperasi .

Kegiatan yang bertujuan untuk mengidentifikasi dan menganalisis permasalahan pada koperasi yang mengalami kesulitan penyelenggaran RAT, terutama pada koperasi di wilayah Lombok Barat, diperlukan agar 
dapat dipetakan masalah mendasar yang menghambat koperasi dalam penyelenggaraan RAT secara periodik. Melalui kegiatan kunjungan lapangan terhadap koperasi yang mengalami permasalahan, wawancara mendalam (in-depth interview) serta brainstrorming yang melibatkan pengurus koperasi, diskusi dengan tenaga Petugas Penyuluh Koperasi Lapangan (PPKL) serta dinas koperasi akan didapatkan solusi yang tepat sesuai untuk mengatasi masalah dalam koperasi yang bermasalah RAT sesuai dengan kondisi riil koperasi. Lebih jauh lagi melalui kegiatan ini akan dapat membantu pihak Dinas Koperasi untuk menentukan bentuk pembinaan dan pengawasan yang sesuai kebutuhan koperasi sehingga dapat memperkuat kelembagaan koperasi.

\section{METODE KEGIATAN}

Kegiatan pengabdian kepada masyarakat ini bertujuan memberikan informasi yang berguna dan relevan dalam mengatasi permasalahan dan kendala beberapa pada koperasikoperasi di wilayah Lombok Barat yang tidak menyelenggarakan Rapat
Anggota Tahunan (RAT) sehingga dapat dilakukan pendekatan yang lebih tepat untuk mengatasi permasalahan tersebut. Penyelenggaraan RAT secara periodik merupakan bentuk akuntabilitas koperasi atas tanggungjawab pengurus kepada anggota koperasi. Pada koperasi-koperasi yang mengalami kendala RAT seperti ini, tidak ada kegiatan usaha dan kepengurusan tidak berjalan sebagaimana mestinya koperasi tidak mampu mempertanggungjawabkan pengelolaan koperasi dalam bentuk Rapat Anggota Tahunan. Kegiatan ini sebagai bentuk tindak lanjut dari survey pendahuluan (preliminary survey) akhir tahun sebelumnya yang kemudian dilakukan pendalaman dalam kegiatan pengabdian kepada masyarakat ini. Oleh karena itu dibutuhkan usaha untuk mengetahui dan mengidentifikasi permasalahan mendasar yang terjadi dalam aspek pengelolan (manajerial) maupun keuangan pada koperasi yang mengalami kendala dalam penyelenggaraan RAT. 


$$
\text { Untuk mencapai tujuan dari }
$$
kegiatan pengabdian kepada masyarakat ini dilakukan kunjungan kepada koperasi yang bermasalah dalam RAT, pertemuan dengan pengurus koperasi serta pelibatan Petugas Pendamping Koperasi Lapangan (PPKL) untuk mengidentifikasi masalah, penyebab, dampak serta solusi yang dapat dilakukan untuk mengatasi masalah riil yang dihadapi koperasi dan pendekatan yang tepat dalam mengatasinya. Adapun pendekatan atau metode yang digunakan dalam melaksanakan kegiatan pengabdian kepada masyarakat pada koperasi adalah sebagai berikut :

1. Mengumpulkan data koperasi aktif dan non aktif serta koperasi yang mengalami permasalahan RAT dari Dinas Koperasi Kabupaten Lombok Barat dan selanjutnya menetapkan koperasi bermasalah RAT yang akan dikunjungi dengan terlebih dahulu berkomunikasi dengan pengurus yang dapat ditemui serta melibatkan petugas PPKL untuk mendampingi.
2. Mengidentifikasi kendala, kesulitan dan permasalahan yang dihadapi koperasi dalam penyelenggaraan Rapat Anggota Tahunan (RAT) yang dilakukan dengan cara diskusi dan brainstrorming dengan koperasi yang mengalami permasalah Rapat Anggota Tahunan (RAT), tenaga Petugas Penyuluh Koperasi Lapangan (PPKL) serta dinas koperasi terutama bagian pembinaan kelembagaan koperasi.

3. Menyiapkan formulir kunjungan lapangan untuk melakukan survey terhadap koperasi-koperasi yang mengalami masalah dan kendala dalam penyelenggaran Rapat Anggota Tahunan (RAT) sehingga dapat mengidentifikasi masalah riil dalam pengelolaan manajerial, pengembangan usaha dan keuangan koperasi.

4. Menentukan waktu dan jadwal pelaksanaan kegiatan kunjungan lapangan koperasi dengan pertimbangan memilih waktu yang sesuai sehingga dapat menemui pengurus koperasi secara langsung. 
5. Melakukan kunjungan lapangan pada koperasi-koperasi yang mengalami masalah dan kendala dalam penyelenggaran Rapat Anggota Tahunan (RAT) untuk melakukan tanya jawab dan pendalaman masalah serta diskusi tentang masalah yang terjadi dalam koperasi.

6. Melakukan telaah dan analisis hasil kunjungan lapangan koperasi dengan melakukan tabulasi data dan pendalaman bahasan terhadap masalah yang ditemukan ketika kunjungan lapangan.

7. Merumuskan dan memetakan masalah, dampak dan solusi dari hasil kunjungan lapangan koperasi yang bermasalah dalam penyelenggaraan RAT.

8. Merumuskan masukan dan rekomendasi perbaikan mengenai pendekatan yang sesuai dengan masalah riil yang dihadapi koperasi yang mengalami hambatan penyelenggaraan RAT sehingga Dinas terkait dapat melakukan pembinaan dan pengawasan yang lebih sesuai dengan permasalahan dan kebutuhan riil koperasi.

\section{HASIL DAN PEMBAHASAN}

$$
\text { Berdasarkan hasil kunjungan }
$$

pada koperasi, diskusi dan pendalaman wawancara dengan pengurus, tenaga pendamping lapangan koperasi dan Petugas Penyuluh Koperasi Lapangan (PPKL) dapat diidentifikasi beberapa hal yang berkaitan dengan permasalahan dalam koperasi, peran tenaga pendamping koperasi serta peran kelembagaan Dinas Koperasi dalam pengawasan dan pembinaan terhadap kinerja operasional koperasi-koperasi yang ada di wilayah kerja Lombok Barat. Dokumentasi dari kegiatan adalah sebagai berikut :

\section{Peran Tenaga Pendamping Koperasi}

Tujuan dari ini untuk memahami permasalahan dari perspektif tenaga pendamping koperasi. Kegiatan dimulai dengan cara tenaga PPKL mengisi form daftar Isian PPKL yang meliputi koperasi yang didampingi, bentuk/model pembinaan yang dilakukan, penilaian terhadap koperasi yang dibina dari aspek manajerial dan keuangan, upaya yang telah dilakukan oleh PPKL untuk mendorong kegiatan operasional 56

Available online : http://abdiinsani.unram.ac.id 
koperasi. PPKL memberikan gambaran serta mengidentifikasi permasalahan dan pola pembinaan masing-masing koperasi di wilayahnya serta memberikan rekomendasi yang berkaitan dengan koperasi. Hasil identifikasi dan telaah data isian/hasil laporan PPKL terdapat berbagai kendala dalam penyusunan RAT baik masalah internal maupun internal koperasi. Secara internal permasalahan berkaitan dengan aspek administrasi, pengelolaan usaha dan keuangan koperasi.

Secara administrasi sebagian besar pengurus koperasi masih lemah dalam melakukan pencatatan usaha dan mendokumentasikan catatan karena kurangnya pemahaman dan pengetahuan tentang cara pembukuan dan penyusunan laporan keuangan koperasi.

Masalah internal koperasi lainnya berkaitan dengan aspek manajerial seperti pergantian pengurus tapi belum ada serah terima dokumen sehingga pengganti tidak dapat melanjutkan kegiatan administrasi, pengurus sibuk sehingga tidak fokus dalam mengelola koperasi, pengurus pindah tugas/pensiun sehingga pengurus tidak dapat berkoordinasi dengan pengurus lainnya. Masalah eksternal berkaitan dengan peran pengawasan dan pembinaan secara kelembagaan oleh dinas Koperasi yang kurang optimal sesuai harapan pengurus koperasi. Beberapa koperasi faktanya sudah tidak ada kegiatan usaha sehingga tidak aktif secara operasional namun masih tercatat sebagai koperasi aktif.

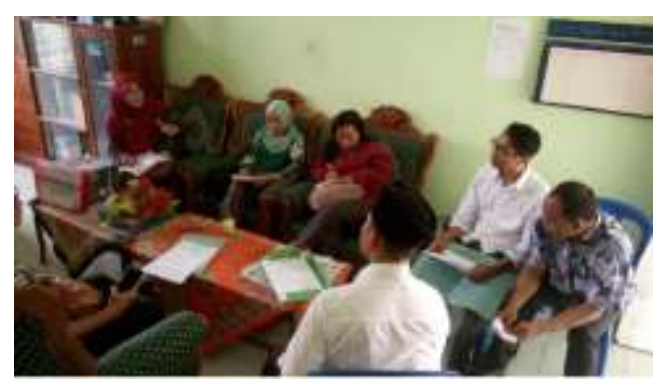

Gambar 1. Diskusi dengan pengurus koperasi dan tenaga pendamping lapang

2. Identifikasi Permasalahan Melalui Kegiatan Kunjungan Koperasi

Tujuan dilakukan kunjungan lapangan koperasi adalah melakukan pemetaan terhadap koperasi yang belum melakukan RAT di Kabupaten Lombok Barat dengan cara mengidentifikasi aktivitas koperasi dan kepengurusan, permasalahan yang dihadapi sehingga tidak melakukan RAT, pola pembinaan oleh PPKL dan 
Dinas Koperasi serta harapan Koperasi.

Sebanyak 15 koperasi yang belum melakukan RAT telah dikunjungi berdasarkan data dari Dinas Koperasi Kabupaten Lombok Barat, yang tersebar di Kecamatan Gerung, Kuripan, Narmada, Batulayar dan Gunungsari.

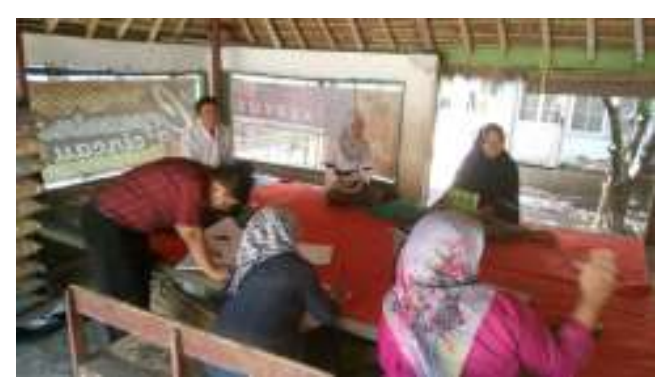

Gambar 2. Kunjungan lapang koperasi tani (koptan)

Dalam melakukan kunjungan lapangan telah disiapkan daftar pertanyaan dan meminta informasi dan klarifikasi dari pihak pengurus koperasi yang diisikan pada form yang telah disiapkan. Adapun indikator yang dinilai dalam kunjungan lapangan koperasi adalah berkaitan dengan informasi umum koperasi dan hasil kunjungan. Informasi umum berkaitan dengan nama dan alamat koperasi, bidang usaha (KSU/USP/Waserda, nama PPKL, tahun Buku RAT terakhir dan tanggal pelaksanaan serta pengurus koperasi yang ditemui.
Informasi hasil kunjungan bertujuan untuk mendapatkan data tentang alasan tidak melakukan RAT, kegiatan operasional/perkembangan usaha, aktivitas kepengurusan yang meiputi susunan pengurus, perkembangan jumlah anggota dan fungsi pengawas koperasi. Selain itu informasi hasil kunjungan juga mengidentifikasi bentuk kegiatan pencatatan / pembukuan / pelaporan keuangan dan perencanaan koperasi dan ketersediaan dokumen koperasi seperti buku dan catatan keuangan yang ada seperti $A D$ dan ART, buku penerimaan kas dan pengeluaran kas, Buku Simpanan Pokok / Wajib / Sukarela, Buku Inventaris, Buku Catatan Piutang/Pinjaman yang diberikan Koperasi, Buku Catatan Utang/Kewajiban Koperasi, Dokumen Laporan RAT terakhir serta Buku dan dokumen lainnya yang relevan.

Berdasarkan hasil kunjungan lapangan dapat dirumuskan beberapa informasi umum dan informasi terinci mengenai permasalahan dalam koperasi. Sebagian besar bentuk usaha koperasi adalah simpan pinjam (USP) dan Waserda serta KSU. Permasalahan 
RAT memberikan informasi bahwa Koperasi tidak melakukan RAT berkisar antara 2-3 tahun, bahkan ada koperasi yang tidak RAT hampir 10 tahun tapi masih terhitung sebagai koperasi aktif, sedangkan menurut Regulasi Koperasi harus melakukan RAT setiap tahun paling lama 2 tahun. Pengurus Koperasi yang ditemui relatif terbatas karena kesibukan, umumnya hanya bertemu perwakilan dari pengurus seperti Ketua, sekretaris dan Bendahara.

Kendala yang dihadapi oleh Koperasi sehingga tidak dapat melakukan RAT disebabkan beberapa faktor, seperti : tidak paham cara pembukuan dan pelaporan keuangan sehingga tidak bisa melakukan RAT sebagai bentuk pertanggungjawaban atas pengelolaan koperasi. Faktor lain berkaitan dengan terjadinya permasalahan dalam struktur kepengurusan yang menyebabkan pengelolaan administrasi dan pencatatan keuangan menjadi berhenti (tidak dilakukan). Adapun perubahan dalam struktur pengurusan terutama disebabkan oleh : (1) pengurus lama pindah tugas (mutasi) dan pensiun sehingga tidak ada yang menjalankan kegiatan koperasi baik administrasi maupun operasional; (2) tidak ada berita acara serah terima dokumen koperasi dari pengurus lama ke pengurus baru, sehingga pengurus baru tidak dapat melanjutkan pengelolaan; dan (3) tidak ada koordinasi antar pengurus karena kesibukan masing-masing sehingga menyulitkan dalam pengelolaan kegiatan operasional dan administrasi koperasi.

Kegiatan operasional koperasi tidak berjalan sehingga tidak dapat melaporkan kegiatan hasil usaha koperasi. Faktor-faktor yang berpotensi dapat menghambat kegiatan operasional koperasi adalah : aktivitas simpan pinjam tidak berjalan (bergulir) karena piutang anggota yang macet; kurangnya (tidak adanya) dana kas untuk menjalankan operasional koperasi dan kesulitan dalam memperoleh bahan baku terutama pada koperasi tani (koptan) dikarenakan harga bahan baku (seperti rotan) yang cenderung fluktuatif dan meningkat. 


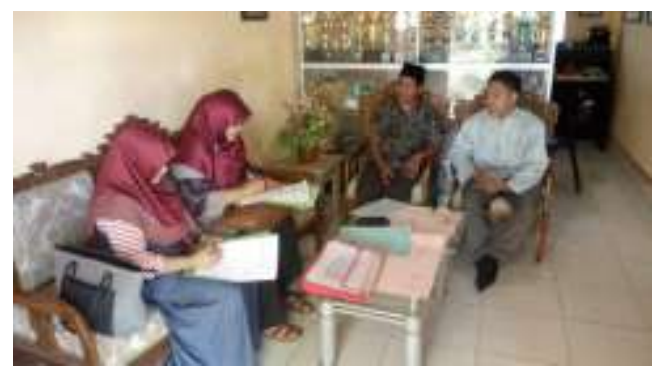

Gambar 3. Wawancara

dengan

manajer koperasi

\section{Pendekatan dan Perbaikan dalam pengelolaan Koperasi}

Melalui kunjungan ke koperasi juga dilakukan pendalaman tentang bentuk dan kegiatan pembinaan dan pengawasan dari tenaga pendamping koperasi (PPKL) dan Dinas Koperasi serta Peran Pengawas dan Pembina Koperasi dengan melakukan tanya jawab dan diskusi intensif. Hasil dari kunjungan juga dapat mengungkap harapan dari pengurus koperasi terhadap Pola Pembinaan baik dari tenaga pendamping koperasi (PPKL), fungsi pengawas maupun pembina koperasi dan Dinas Koperasi serta fungsi pengawas dan pembina koperasi yang selama ini telah berjalan.

Berdasarkan telaah terhadap permasalahan dan kendala dalam melakukan RAT, maka direkomendasikan beberapa pendekatan yang dapat dilakukan.
Diperlukan peningkatan peran dan fungsi kelembagaan dari Dinasi Koperasi terkait dengan melakukan fungsi pengawasan yang lebih ketat sehingga dapat mengkategorikan koperasi aktif dan tidak aktif. Pola pembinaan dapat dilakukan dengan pendampingan secara intens terhadap koperasi terutama terkait dengan pembukuan dan penyusunan laporan keuangan koperasi serta manajemen usaha. Bentuk pengawasan dan pembinaan dari Dinas terkait umumnya menggunakan pendekatan top-bottom sehingga sulit mengetahui permasalahan riil yang dihadapi koperasi di lapangan. Koperasi memerlukan fungsi pembinaan yang lebih sesuai dengan kebutuhan pengembangan koperasi seperti pelatihan keuangan dan manajerial serta pendampingan yang dirasakan masih kurang optimal dilakukan oleh fungsi kelembagaan dari Dinas Koperasi yang cenderung hanya fokus pada hasil sasaran akhir berupa RAT.

$$
\text { Berkaitan dengan peran }
$$
pendamping koperasi, dirasa perlu untuk menelaah kembali indikator capaian kinerja PPKL yang selama ini 
berdasarkan frekuensi kunjungan dengan target 5 kali sebulan atau 60 kali setahun menjadi cara pengukuran kinerja yang lebih reasonable misalnya target koperasi yang bisa RAT dalam setahun dan deskripsi secara jelas tentang kegiatan yang diakukan PPKL ketika kunjungan oleh masing-masing PPKL sehingga hasilnya lebih terukur. PPKL diharapkan lebih intensif dalam melakukan pendampingan tidak hanya sekedar kunjungan saja tetapi juga membantu memberikan pemahaman terhadap aspek teknis tentang pembukuan dan penyusunan laporan keuangan koperasi sebagai persiapan pelaksanaan RAT. Koperasi yang kegiatan operasionalnya masih relatif terbatas juga berkeinginan mendapatkan kesempatan secara merata untuk dilibatkan dalam kegiatan pelatihan dan penyuluhan yang diadakan oleh Dinas Koperasi Kabupaten Lombok Barat, tidak hanya pada koperasi-koperasi yang telah maju dan mandiri. Bentuk kegiatan pelatihan atau penyuluhan yang diinginkan adalah pembukuan / akuntansi koperasi dan manajemen usaha.
Koperasi juga menginginkan adanya tambahan modal koperasi untuk meningkatkan usahanya baik berupa dana uang tunai untuk tambahan dana simpan pinjam atau berupa alat kerja yang mendukung kegiatan anggota koperasi seperti alat kerja jala dan perahu bagi koperasi nelayan. Adanya tindak lanjut dari kegiatan penyuluhan dan pelatihan berupa pendampingan secara intensif sehingga pada akhirnya koperasi akan mandiri dalam pembukuan dan pelaporan keuangan koperasi. Jika upaya-upaya ini dapat dilakukan maka penyelenggaraan RAT bukan menjadi masalah lagi koperasi.

\section{KESIMPULAN DAN SARAN}

\section{Kesimpulan}

1. Upaya nyata diperlukan untuk mengidentifikasi kendala dan permasalahan yang terjadi dalam pengelolaan koperasi, terutama pada koperasi yang mengalami kesulitan dalam penyelenggaraan Rapat Anggota Tahunan (RAT) melalui pemetaan tentang masalah manajerial dan keuangan pada 


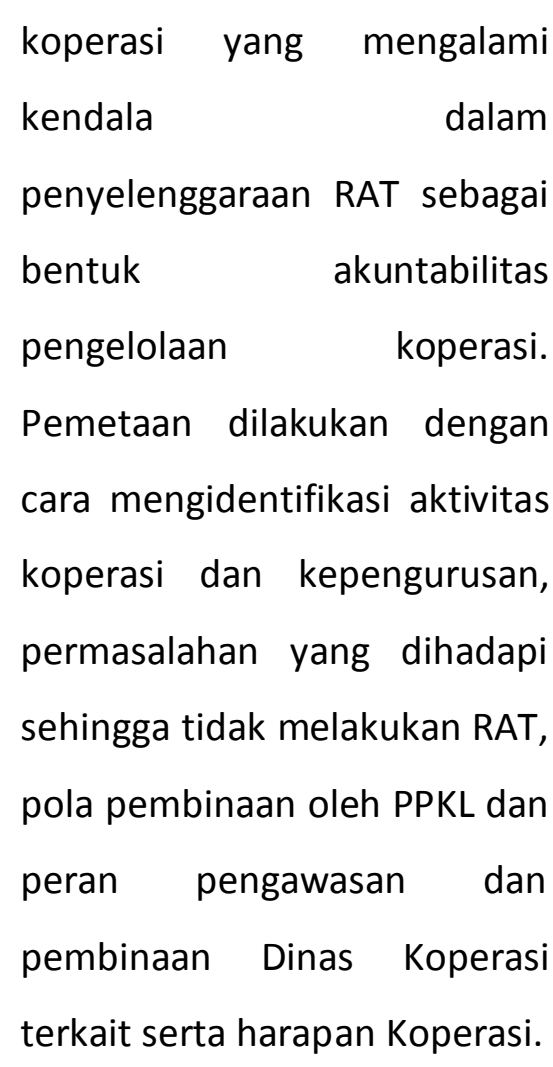

2. Permasalahan koperasi yang mengalami kendala dalam penyelenggaraan RAT disebabkan beberapa faktor internal dan manajerial, seperti pengurus tidak memahami cara pembukuan dan pelaporan keuangan, tidak paham dalam manajemen usaha dan permasalahan dalam struktur kepengurusan yang menyebabkan administrasi dan pencatatan keuangan menjadi berhenti (tidak dilakukan) dan kegiatan operasional koperasi menjadi terhambat tidak sesuai dengan yang diharapkan. Dengan kurangnya kemampuan dalam penyusunan laporan keuangan koperasi maka pengurus koperasi lebih mengandalkan peran dari pendamping koperasi seperti petugas penyuluh koperasi lapangan (PPKL).

\section{Saran}

1. Ke depan perlu pendampingan lebih intensif dalam bentuk pelatihan keuangan dan manajemen usaha yang sesuai dengan kebutuhan riil koperasi untuk dapat mendukung akuntabilitas koperasi.

2. Optimalisasi peran dari tenaga pendamping koperasi diperlukan dalam memberikan pendampingan secara teknis untuk pengelolaan keuangan dan penyusunan laporan keuangan koperasi.

3. Peran dari Dinas Koperasi terkait juga sangat diharapkan untuk secara kontinu melakukan pengawasan dan pembinaan koperasi dengan 


$$
\begin{aligned}
& \text { pendekatan yang tepat dan } \\
& \text { sesuai dengan kebutuhan } \\
& \text { koperasi. }
\end{aligned}
$$

\section{UCAPAN TERIMAKASIH}

Terimakasih disampaikan

kepada Lembaga Pengabdian Kepada

Masyarakat Universitas Mataram, yang telah memberikan dukungan dana untuk melaksanakan kegiatan pengabdian kepada masyarakat melalui Dana DIPA BLU (PNBP) Universitas Mataram tahun Anggaran 2018.

\section{DAFTAR PUSTAKA}

Andrian, M. 2015. Banyak Koperasi yang Tidak Aktif ini Kata Disperindagkop Bontang. dalam D. Darwis(ed). http://www.klikbontang.com/b erita-1292. diakses 12 maret 2017

Ismadi, G. 2015. Menteri Koperasi Bekukan 62 Ribu Koperasi. dalam T. Tarmizi (ed). http://www.antaranews.com/b erita/503855/. diakses 5 Februari 2017.

Nasution, M. 2008. Koperasi Menjawab Kondisi Ekonomi Nasional. Pusat Informasi Perkoperasian.

Peraturan Menteri Negara Koperasi dan UKM RI Nomor20/Per/M.KUKM/IX/201 5 tentang Penerapan Akuntabilitas Koperasi. http://www.ditjenpp.kemenku mham.go.id/arsip/bn/2011/bn 580-2011.pdf. diakses 25 Februari 2017.

Peraturan Menteri Koperasi dan Usaha Kecil dan Menengah RI. Nomor : 19 / PER / M.KUKM / IX / 2015. Tentang Penyelenggaraan Rapat Anggota Koperasi.

Rudianto. 2010. Akuntansi Koperasi .Edisi Kedua. Jakarta : Penerbit Erlangga

Undang-Undang Republik Indonesia Nomor 25 Tahun 1992 tentang Perkoperasian.

https://jdih.kemenkeu.go.id/ful Itext/1992/25TAHUN 1992UU. htm diakses pada 4 Mei 2018 